\title{
ENERGY CONSUMPTION AND MATHEMATICAL MODELING OF MICROWAVE DRYING OF DATE
}

\author{
*Mona M. A. Hassan
}

\section{ABSTRACT}

In the present research, drying characteristics and energy requirements for microwave drying of date palm were reported for two varieties of date palm, (Hayani and Zagloul). During the experiments, drying was carried out until the final moisture content reached a level of less than $20 \%(\mathrm{db})$. The experimental data were fitted to six drying models. The models were compared using reduced chi-square $\left(X^{2}\right)$, mean bias error $(M B E)$ and root mean square error (RMSE).They were used to determine the quality of the fit. Page, Modified Page (I) and Linear were the best descriptive models. The effective moisture diffusivity was determined by using Fick's second law and was observed to lie between $8.6 \times 10^{-9}$ and $5.98 \times 10^{-8}$ $\mathrm{m}^{2} / \mathrm{s}$ for the date palm samples. The minimum total energy consumption $(0.08 \mathrm{kWh})$, the minimum specific energy $\left(5.7 \mathrm{MJ} / \mathrm{kgH}_{2} \mathrm{O}\right)$ and maximum drying efficiency (40\%) were computed for drying (Hayani). The maximum total energy consumption $(0.14 \mathrm{kWh})$, the minimum drying efficiency (32\%) and maximum specific energy $\left(7.15 \mathrm{MJ} / \mathrm{kgH}_{2} \mathrm{O}\right)$ were computed for (Zagloul).

Keywords: dates, drying, mathematical model, effective diffusivity, energy consumption.

\section{INTRODUCTION}

he date palm is the fundamental element of the oasis ecosystem. It
plays a vital role in economic production. In Egypt presently the
productive date palm approximately approached1.170 million mg as mentioned in UN Food\& Agriculture Organization (FAO,2005). Microwave heating is based on the transformation of alternating electromagnetic field energy into thermal energy by affecting the polar molecules of a material. Compared with hot air drying, microwave reduces the decline in quality, and provides rapid and effective heat distribution in the material as well (Diaz et al., 2003).

\footnotetext{
*Associate Prof. of Agric. Eng., Fac. of Agric., Zagazig Univ., Egypt.
} 
Different drying methods are used in the drying of fruits and vegetables. Air drying is the most common method in the drying of food stuffs. The major drawback of air-drying is the longer drying period, low drying rates in the falling rate period, worsening of the taste, color and nutritional content of the product, higher drying temperature, low energy efficiency and high costs which is not a desirable situation for food industry (Rayaguru et al., 2011). The desire to eliminate this problem, prevent significant quality loss, and achieve fast and effective thermal processing, has resulted in the increase use of other drying heat sources such as microwave and infrared (IR) drying. Microwave drying is more rapid, more uniform and more highly energy efficient compared to conventional hot air drying and infrared drying

(Minaei et al., 2012). In recent years, microwave drying has gained popularity as an alternative drying method for a variety of food products such as fruit, vegetable and dairy product(Demirhan et al., 2012). Tippayawong et al., 2008, reported that in microwave drying, the quick absorption of energy by water molecules causes rapid evaporation of water, resulting in high drying rates of the food. The drying time can be greatly reduced by applying the microwave energy to the dried material. Due to the concentrated energy of a microwave drying system, only $20 \%-$ $35 \%$ of the floor space is required, as compared to conventional heating and drying equipment (Vadivambal and Jayas, 2007). Also, it has been suggested that microwave energy should be applied in the falling rate period for drying (Maskan, 2000). In the drying industry, the most important aim is to use lowest energy to extract the most moisture for obtaining optimum product storing conditions. The aim of this study was to (i) determine the influence of microwave power on the drying kinetic of date palm, (ii) compare the measured findings obtained during the drying of date palm with the predicted values obtained with six mathematical models, (iii) calculate the effective moisture diffusivity and specific energy.

\section{MATERIALS AND METHODS}

Dates, procured from the local market, were used in the present study. Two varieties of dates were used (Zagloul and Hayani). They were stored at a temperature of $8 \pm 0.5{ }^{\circ} \mathrm{C}$ until the drying process. The samples were 
divided into four sup samples as follows:- The first sub sample of date(Zagloul) was coded as $\left(\mathrm{T}_{1}\right)$, the second sub sample of date(Zagloul without kernel) was coded as $\left(\mathrm{T}_{2}\right)$, the third sub sample of (Hayani) was coded as $\left(\mathrm{T}_{3}\right)$ and the fourth sub sample of (Hayani rutab without kernel and crust ) was coded as $\left(\mathrm{T}_{4}\right)$. To determine the initial moisture content, 30 $\mathrm{g}$ of samples were dried in an oven (Memmert UM-400) at $105{ }^{\circ} \mathrm{C}$ for 3 days. A domestic microwave oven (KOC-185V, Daewoo) with maximum output of $1000 \mathrm{~W}$ at $50 \mathrm{MHz}$ was used for the date drying experiments. The oven has a fan for air flow in drying chamber and cooling of magnetron. The moisture from drying chamber was removed with this fan by passing it through the openings on the right side of the oven wall to the outer atmosphere. The microwave dryer was operated by a control terminal which could control both microwave power level and emission time. Experiments were performed at masses of $100 \mathrm{~g}$ for each treatment. The moisture losses of samples were recorded at 30 second intervals during the drying process by a digital balance (Ming Heng K1) with an accuracy of $\pm 0.01 \mathrm{~g}$. For measuring the mass of the sample during experimentation, the tray with sample was taken out of the drying chamber, weighed on the digital top pan balance and placed back into the chamber. Drying was carried out until the final moisture content reaches to a level less than $20 \%(\mathrm{db})$.

\section{Drying rate:}

The drying rate is expressed as the amount of the evaporated moisture over time. The drying rate of date samples was calculated using the following equation:

$$
D R=\frac{M_{t-d t}-M_{t}}{d t} g / \min
$$

Where : $\mathrm{M}_{\mathrm{t}-\mathrm{dt}}$ and $\mathrm{M}_{\mathrm{t}}$ are the moisture contents(db\%) at $\mathrm{t}-\mathrm{dt}$ and $\mathrm{t}$, respectively, and dt is the drying time period ( $\mathrm{min})$.

\section{Energy consumption and drying efficiency:}

-Energy consumption by the microwave oven equals:

$$
Q_{t}=p \times t \quad k W h
$$


where, $\mathrm{Q}_{\mathrm{t}}$ represents total energy consumption in each drying bout, $\mathrm{kWh}$; $\mathrm{P}$ is the microwave power, $\mathrm{kW}$; and $\mathrm{t}$ is drying time, $\mathrm{h}$.

-The microwave drying efficiency was calculated as the ratio of the heat energy utilized for evaporating water from the sample to the heat supplied by the microwave oven (Soysal, 2004; Yongsawatdigul and Gunasekaran, 1996).

$$
\eta=\frac{m_{w} \times \lambda_{w} \times 1000}{p \times t \times 60} \times 100
$$

where, $\eta$ is the microwave drying efficiency, $\% ; m_{w}$ is the mass of evaporated water, $\mathrm{kg}$; and $\lambda_{\mathrm{w}}$ is the latent heat of vaporization of water, $\mathrm{kJ} / \mathrm{kg}$. The latent heat of vaporization of water at the evaporating temperature of $100^{\circ} \mathrm{c}$ was taken as $2257, \mathrm{~kJ} / \mathrm{kg}$ (Hayes, 1987).

-The specific energy consumption was calculated as the energy needed to evaporate a unit mass of water (Mousa and Farid, 2002; Soysal et al., 2006).

$$
Q_{s}=\frac{60 \times 10^{-6} p \times t}{m_{w}}
$$

where, $Q_{s}$ is the specific energy consumption, $\mathrm{MJ} / \mathrm{kgH}_{2} \mathrm{O}$.

\section{Moisture ratio and mathematical modeling:}

-The moisture ratio (MR) was calculated using the equation:

$$
M R=\frac{M_{t}-M_{e}}{M_{o}-M_{e}}
$$

where, MR is the moisture ratio (dimensionless); $M_{t}$ is the moisture content at $\mathrm{t}, \mathrm{db}) ; \mathrm{M}_{\mathrm{e}}$ is the equilibrium moisture content, $\mathrm{db}$; and $\mathrm{M}_{0}$ is the initial moisture content, $\mathrm{db}$. The value of $\mathrm{M}_{\mathrm{e}}$ is relatively small compared with $\mathrm{M}_{\mathrm{t}}$ or $\mathrm{M}_{0}$. Therefore, the moisture ratio (MR) was simplified to $\mathrm{M}_{\mathrm{t}} / \mathrm{M}_{0}$.

Six semi-empirical models were applied to fit the experimental moisture data because they are widely used in drying agriculture products and they are equalities that explain the characteristic of the drying method in a safe way, as listed in Table 1. 
The terms used to evaluate the goodness of the fit of the tested models to the various statistical parameters such as; reduced chi-square $\left(\mathrm{X}^{2}\right)$, mean bias error (MBE) and root mean square error (RMSE) were used to determine the quality of the fit. These parameters can be calculated as following:

$$
\begin{aligned}
& X^{2}=\frac{\sum_{i=1}^{n}\left(M R_{\exp , i}-M R_{p r e, i}\right)^{2}}{N-n} \\
& M B E=\frac{1}{N} \sum_{i=1}^{N}\left(M R_{p r e, i}-M R_{\text {exp } \dot{i}}\right) \\
& R M S E=\left[\frac{1}{N} \sum_{i=1}^{n}\left(M R_{p r e . i}-M R_{\text {exp } \dot{i}}\right)^{2}\right]^{\frac{1}{2}}
\end{aligned}
$$

where $\mathrm{MR}_{\text {exp,i }}$ : is the stands for the experimental moisture ratio found in any measurement, $\mathrm{MR}_{\text {pre, } \mathrm{i}}$ : the predicted moisture ratio for this measurement, $\mathrm{N}$ : the number of observations and $\mathrm{n}$ : is the number constants.

\begin{tabular}{|c|c|c|c|}
\hline $\begin{array}{c}\text { Model } \\
\text { no }\end{array}$ & Model name & References & Model \\
\hline 1 & Newton & $\begin{array}{l}\text { Liu and Bakker (1997) ; } \\
\text { O'Callaghan et al (1971) }\end{array}$ & $\begin{array}{l}\mathrm{MR}=\exp (- \\
\mathrm{kt})\end{array}$ \\
\hline 2 & Page & $\begin{array}{c}\text { Agrawal and Singh (1977) } \\
\text {; Zhang and Litchfield } \\
\text { (1991) }\end{array}$ & $\begin{array}{l}\mathrm{MR}=\exp (- \\
\left.\quad \mathrm{kt}^{\mathrm{n}}\right)\end{array}$ \\
\hline 3 & $\begin{array}{l}\text { Modified Page } \\
\text { (I) }\end{array}$ & $\begin{array}{c}\text { Agrawal and Singh (1977) } \\
\text {; Zhang and Litchfield } \\
\text { (1991) }\end{array}$ & $\begin{array}{l}\mathrm{MR}=\exp [- \\
\left.\quad(\mathrm{kt})^{\mathrm{n}}\right]\end{array}$ \\
\hline 4 & Linear & - & $\mathrm{MR}=1+\mathrm{bt}$ \\
\hline 5 & $\begin{array}{l}\text { Henderson and } \\
\text { Pabis } \\
\end{array}$ & $\begin{array}{c}\text { Chhninman (1984); } \\
\text { Westerman et al. (1973) }\end{array}$ & $\begin{array}{c}\mathrm{MR}=\mathrm{a} \exp (- \\
\mathrm{kt})\end{array}$ \\
\hline 6 & $\begin{array}{l}\text { Wang and } \\
\text { Singh }\end{array}$ & Wang and Singh (1978) & $\begin{array}{c}\mathrm{MR}=1+\mathrm{at}+ \\
\mathrm{bt}^{2}\end{array}$ \\
\hline
\end{tabular}

Table (1): Mathematical models given by various authors for the drying curves. 


\section{Determination of effective moisture diffusivity:}

It has been generally accepted that the drying phenomenon of biological materials is controlled by the mechanism of moisture diffusion during the falling rate period. The experimental drying data for the determination of diffusivity coefficients were interpreted by using Fick's second diffusion model, as shown in this equation, has been frequently used to describe the internal moisture transfer during drying process.

$$
\frac{\partial M}{\partial t}=D_{e f f} \nabla^{2} M
$$

The solution of diffusion equation for slab geometry is solved by Crank (1975) and supposed uniform initial moisture distribution, negligible external resistance, constant diffusivity and negligible shrinkage:

$$
M R=\frac{8}{\pi^{2}} \sum_{n=0}^{\infty} \frac{1}{(2 n+1)^{2}} \exp \left(-\frac{(2 n+1)^{2} \pi^{2} D_{e f f} t}{4 L^{2}}\right)
$$

where $D_{\text {eff }}$ is the effective moisture diffusivity $\left(\mathrm{m}^{2} / \mathrm{s}\right), t$ is the time (s), $L$ is the half thickness of samples $(\mathrm{m})$ and $n$ is a positive integer. For long drying times, a limiting of this equation is obtained and expressed in a logarithmic form (Madamba 2003):

$$
\ln M R=\ln \frac{8}{\pi^{2}}-\frac{\pi^{2} D_{e f f} t}{4 L^{2}}
$$

The effective diffusivity is typically calculated by plotting experimental drying data in terms of $\ln (\mathrm{MR})$ versus time.

\section{RESULTS AND DISCUSSION}

\section{Drying kinetics of dates}

The date palm samples were dried as a single layer at the drying microwave. The variations in moisture ratio of the date palm samples as a function of drying time are presented in Figure 1. It can be seen that the moisture content of the date palm samples decreased with the increase in drying time. It only took 480, 420,360 and 510 second to dry date samples from an initial moisture ratio (MR) of 1 to a final moisture ratio (MR) of 0.07, 0.06, 0.13and 0.05 for $\mathrm{T}_{1}, \mathrm{~T}_{2}, \mathrm{~T}_{3}$ and $\mathrm{T}_{4}$, respectively. The 
drying rates versus drying time and the drying rates versus average moisture content curves of date palm are illustrated in Figures 2 and 3. The drying rates decreased continually with the decrease in moisture content and increasing drying time. It was observed that the drying rates were higher at the beginning of the drying operation, when the product moisture content was higher. The moisture content of the material was very high during the initial phase of the drying. As the drying progressed, the loss of moisture in the product caused a decrease in the absorption of microwave power and resulted in a fall in the drying rate.

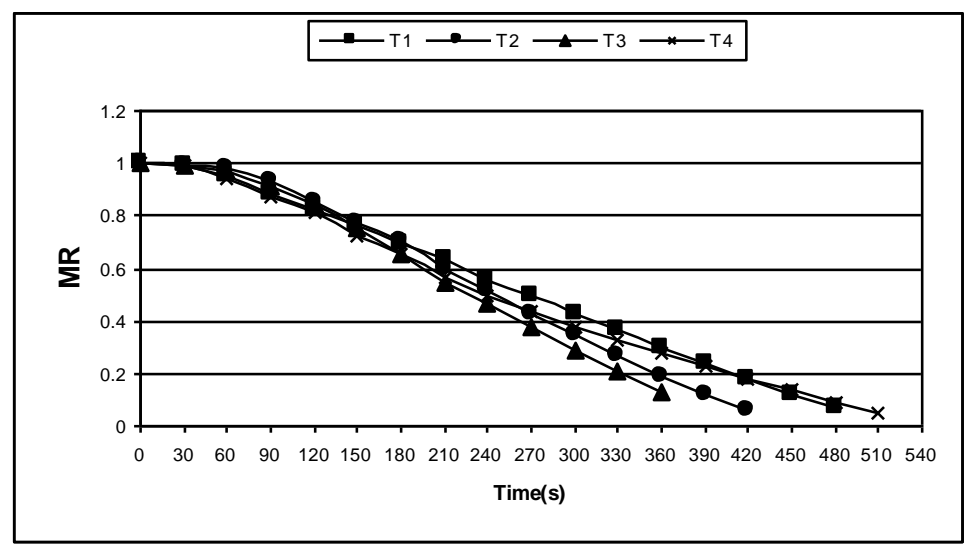

Figure (1): Drying curves of moisture ratio with drying time at different treatments.

\section{Evaluation of the models}

Non-linear regression was used to obtain each parameter value of every model. The results of statistical analyses undertaken on these models are given in table(2). The models were evaluated based on $\mathrm{X}^{2}, \mathrm{MBE}$ and RMSE. Page ,Modified Page (I) and Linear were the best descriptive models.

\section{Effective moisture diffusivity}

The effective moisture diffusivity was calculated by using the method of slopes. According to the experimental data obtained at different drying parameters, the logarithm of moisture ratio values, $\ln (\mathrm{MR})$, were plotted against drying time (t). The linearity of the relationship between $\ln (\mathrm{MR})$ and the drying time is illustrated in Figure 4 . The values of effective moisture diffusivity are $4.96 \times 10^{-8}, 5.98 \times 10^{-8}, 3.4 \times 10^{-8}$ and $8.6 \times 10^{-9} \mathrm{~m}^{2} / \mathrm{s}$ 
for $T_{1}, T_{2}, T_{3}$ and $T_{4}$ respectively. Based on these results, $T_{3}$ had the highest effective moisture diffusivity compared with other treatments. The values of $D_{\text {eff }}$ obtained from this study lie within in general range $10^{-}$ 12 to $10^{-8} \mathrm{~m}^{2} / \mathrm{s}$ for drying of food materials (Zogzas et al. 1996). These values are comparable with $4.56 \times 10^{-10}$ to $8.5 \times 10^{-10} \mathrm{~m}^{2} / \mathrm{s}$ for air-drying of okra at $70{ }^{\circ} \mathrm{C}$ (Adedeji et al. 2008), $1.25 \times 10^{-9}$ to $2.20 \times 10^{-9} \mathrm{~m}^{2} / \mathrm{s}$ for carrot at $35-55{ }^{\circ} \mathrm{C}$ (Kaya et al. 2009), $6.92 \times 10^{-9}$ to $14.59 \times 10^{-9} \mathrm{~m}^{2} / \mathrm{s}$ for white radish at $40-60{ }^{\circ} \mathrm{C}$ (Lee and Kim 2009), $1.55 \times 10^{-9}$ to $16.5 \times 10^{-9} \mathrm{~m}^{2} / \mathrm{s}$ for mushroom at $50-60{ }^{\circ} \mathrm{C}$ (Arumuganathan et al. 2009), $1.92 \times 10^{-10}$ to $3.55 \times 10^{-10} \mathrm{~m}^{2} / \mathrm{s}$ for potato at $40-85{ }^{\circ} \mathrm{C}$ (Hassini et al. 2007) and $6.36 \times 10^{-11}$ to $9.75 \times 10^{-9} \mathrm{~m}^{2} / \mathrm{s}$ for sweet potato at 50-80C (Falade and Solademi 2010).

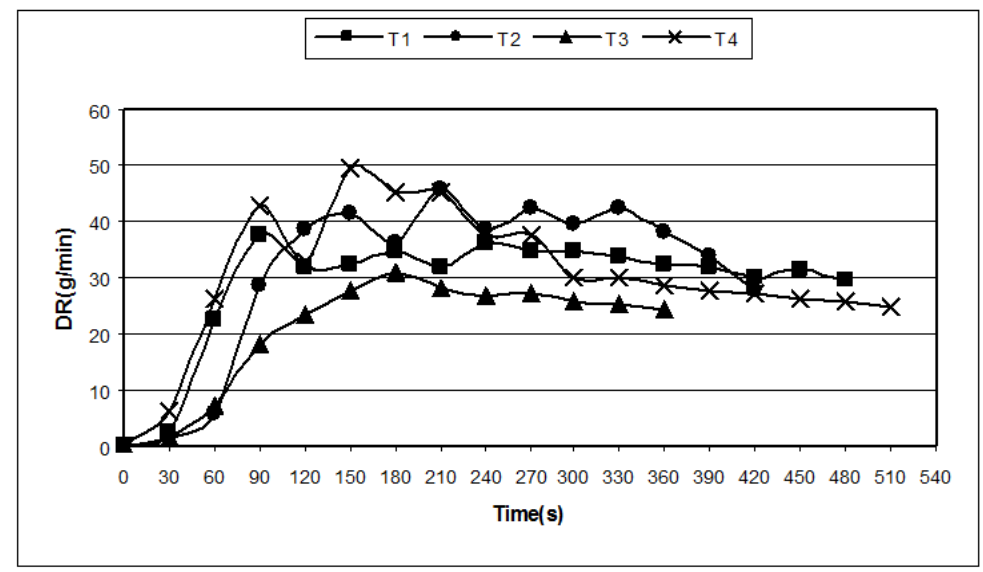

Figure( 2): Drying curves of drying rate with drying time at different treatments.

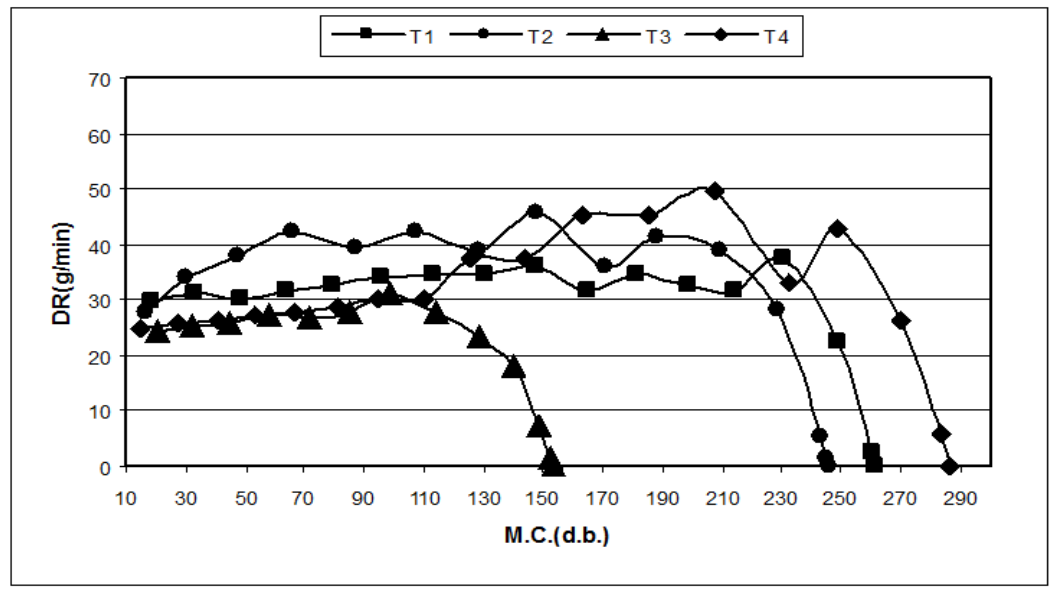

Figure (3): Drying curves of drying rate with moisture content at different treatments. 


\section{Energy consumption}

Figure 5 shows the variations of drying efficiency values for dates samples drying under microwave heating. Results showed that the drying efficiency values decreased continuously with time and increased as the moisture content were increased. The average drying efficiency, energy consumption and specific energy consumption for a charge of the dryer and the energy needed for drying of dates samples are given in table 3. As it is understood from this table, the minimum total energy consumption $(0.08 \mathrm{kWh})$, the minimum specific energy $\left(5.7 \mathrm{MJ} / \mathrm{kgH}_{2} \mathrm{O}\right)$ and maximum drying efficiency (40\%) were computed for drying dates samples $\left(\mathrm{T}_{3}\right)$. The maximum total energy consumption $(0.14 \mathrm{kWh})$, the minimum drying efficiency (32\%) and maximum specific energy $\left(7.15 \mathrm{MJ} / \mathrm{kgH}_{2} \mathrm{O}\right)$ were computed for drying dates samples $\left(\mathrm{T}_{1}\right)$.

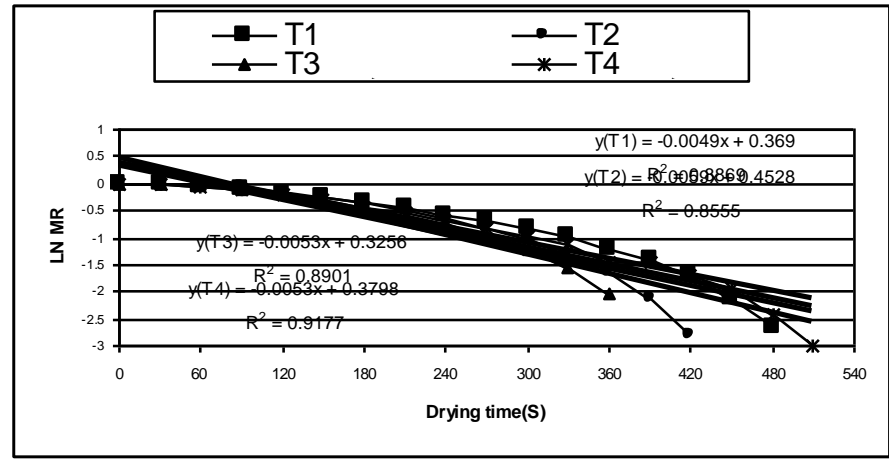

Figure (4): Plot of $\ln (\mathrm{MR})$ versus drying time used for the determination of effective moisture diffusivity.

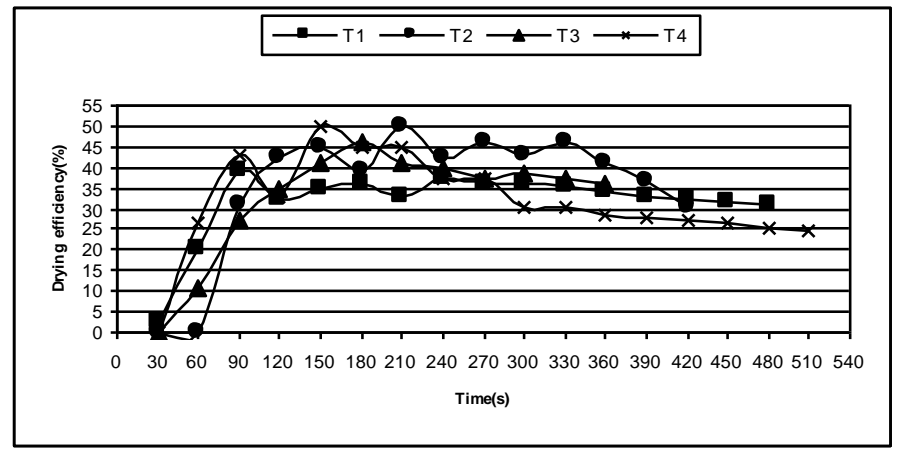

Figure ( 5 ):Variations of drying efficiency as a function of time for microwave drying of dates samples. 
Table( 2 ): Statistical analysis on the modeling of moisture contents and drying time for the microwave dried date palm.

\begin{tabular}{|c|c|c|c|c|c|c|}
\hline MODEL & $\begin{array}{l}\text { TRE } \\
\text { ATM } \\
\text { ENTS } \\
\end{array}$ & $\begin{array}{c}\text { MODEL } \\
\text { CONSTANTS }\end{array}$ & $\mathrm{R}^{2}$ & MBE & $X^{2}$ & RMSE \\
\hline \multirow[t]{4}{*}{ Newton } & $\mathrm{T}_{1}$ & $\mathrm{~K}=0.0049$ & 0.88 & -0.20357 & 0.0426 & 0.206 \\
\hline & $\mathrm{T}_{2}$ & $\mathrm{~K}=0.0059$ & 0.85 & -0.23769 & 0.0688 & 0.2622 \\
\hline & $\mathrm{T}_{3}$ & $\mathrm{~K}=0.0053$ & 0.89 & -0.20455 & 0.0476 & 0.218 \\
\hline & $\mathrm{T}_{4}$ & $\mathrm{~K}=0.0053$ & 0.91 & -0.1775 & 0.0355 & 0.188 \\
\hline \multirow[t]{4}{*}{ Page } & $\mathrm{T}_{1}$ & $\mathrm{k}=0.00002, \mathrm{n}=1.846$ & 0.99 & -0.00714 & 0.0007 & 0.0261 \\
\hline & $\mathrm{T}_{2}$ & $\mathrm{k}=0.000004, \mathrm{n}=2.17$ & 0.99 & -0.00077 & 0.0003 & 0.0177 \\
\hline & $\mathrm{T}_{3}$ & $\mathrm{k}=0.000037, \mathrm{n}=1.84$ & 0.98 & -0.04818 & 0.0031 & 0.052 \\
\hline & $\mathrm{T}_{4}$ & $\mathrm{k}=0.00003, \mathrm{n}=1.8$ & 0.96 & -0.00062 & 0.0006 & 0.0241 \\
\hline \multirow{4}{*}{$\begin{array}{l}\text { Modified } \\
\text { Page (I) }\end{array}$} & $\mathrm{T}_{1}$ & $\mathrm{k}=0.00324, \mathrm{n}=1.846$ & 0.99 & -0.01063 & 0.0009 & 0.0279 \\
\hline & $\mathrm{T}_{2}$ & $\mathrm{k}=0.0035, \mathrm{n}=2.1777$ & 0.99 & -0.005 & 0.0003 & 0.0171 \\
\hline & $\mathrm{T}_{3}$ & $\mathrm{k}=0.004, \mathrm{n}=1.848$ & 0.98 & -0.04917 & 0.0039 & 0.056 \\
\hline & $\mathrm{T}_{4}$ & $\mathrm{k}=0.0034, \mathrm{n}=1.83$ & 0.96 & -0.01 & 0.0008 & 0.0266 \\
\hline \multirow[t]{4}{*}{ Linear } & $\mathrm{T}_{1}$ & $\mathrm{~b}=-.0021$ & 0.99 & -0.05412 & 0.0035 & 0.0576 \\
\hline & $\mathrm{T}_{2}$ & $\mathrm{~b}=-0.0025$ & 0.98 & -0.105 & 0.0098 & 0.0954 \\
\hline & $\mathrm{T}_{3}$ & $\mathrm{~b}=-0.0026$ & 0.98 & -0.0975 & 0.0115 & 0.1027 \\
\hline & $\mathrm{T}_{4}$ & $b=-0.002$ & 0.99 & -0.01706 & 0.0013 & 0.0350 \\
\hline \multirow{4}{*}{$\begin{array}{l}\text { Henderson } \\
\text { and Pabis }\end{array}$} & $\mathrm{T}_{1}$ & $\mathrm{k}=.0049, \mathrm{a}=1.442$ & 0.88 & 0.88 & -0.0175 & 0.0104 \\
\hline & $\mathrm{T}_{2}$ & $\mathrm{k}=.0059, \mathrm{a}=1.569$ & 0.85 & -0.02714 & 0.0197 & 0.13 \\
\hline & $\mathrm{T}_{3}$ & $\mathrm{k}=.0053, \mathrm{a}=1.38$ & 0.89 & 0.89 & -0.0258 & 0.0106 \\
\hline & $\mathrm{T}_{4}$ & $\mathrm{k}=.0052, \mathrm{a}=1.46$ & 0.91 & 0.91 & 0.0471 & 0.0679 \\
\hline \multirow[t]{4}{*}{$\begin{array}{l}\text { Wang and } \\
\text { Singh }\end{array}$} & $\mathrm{T}_{1}$ & $\begin{array}{l}\mathrm{b}=-0.0000004 \\
\mathrm{a}=-.0019\end{array}$ & 0.99 & -0.044 & 0.0025 & 0.046 \\
\hline & $\mathrm{T}_{2}$ & $\begin{array}{l}\mathrm{b}=-0.000002, \\
\mathrm{a}=-.0018\end{array}$ & 0.99 & -0.075 & 0.0078 & 0.081 \\
\hline & $\mathrm{T}_{3}$ & $\begin{array}{l}\mathrm{b}=-.000003 \\
\mathrm{a}=-.0016\end{array}$ & 0.99 & -0.134 & 0.0287 & 0.1545 \\
\hline & $\mathrm{T}_{4}$ & $\begin{array}{l}\mathrm{b}=-0.0000004, \\
\mathrm{a}=.0019\end{array}$ & 0.99 & -0.247 & 0.0944 & 0.2886 \\
\hline
\end{tabular}


Table (3): Average values of drying efficiency, total energy consumption and specific energy consumption during microwave drying of dates samples.

\begin{tabular}{|l|c|c|c|}
\hline & $\eta_{(\%)}$ & $\mathrm{Q}_{\mathrm{t}(\mathrm{kWh})}$ & $\mathrm{Q}_{\mathrm{s}(\mathrm{MJ} / \mathrm{kg})}$ \\
\hline $\mathrm{T}_{1}$ & 32 & 0.14 & 7.15 \\
\hline $\mathrm{T}_{2}$ & 35.7 & 0.11 & 6.3 \\
\hline $\mathrm{T}_{3}$ & 40 & 0.08 & 5.7 \\
\hline $\mathrm{T}_{4}$ & 32 & 0.13 & 7.05 \\
\hline
\end{tabular}

\section{CONCLUSIONS}

The drying kinetics of the dates samples was investigated in a microwave dryer as a single layer with two varieties of date palm, The samples divided into four sup samples as follows:- The first sub sample of date(Zagloul) was coded as $\left(\mathrm{T}_{1}\right)$, The second sub sample of date(Zagloul without kernel) was coded as $\left(\mathrm{T}_{2}\right)$, The third sub sample of (Hayani) was coded as $\left(\mathrm{T}_{3}\right)$ and The fourth sub sample of (Hayani without kernel and crust) was coded as $\left(\mathrm{T}_{4}\right)$. It can be seen that the moisture content of the date palm samples decreased with the increase in drying time. It only took 480, 420,360 and 510 second to dry date samples from an initial moisture ratio (MR) of 1 to a final moisture ratio (MR) of $0.07,0.06,0.13$ and 0.05 for $T_{1}, T_{2}, T_{3}$ and $T_{4}$, respectively. Non-linear regression was used to obtain each parameter value of every model. The models were evaluated based on $\mathrm{X}^{2}$, MBE and RMSE. Page ,Modified Page (I) and Linear were the best descriptive models. The values of effective moisture diffusivity are $4.96 \times 10^{-8}, 5.98 \times 10^{-8}, 3.4 \times 10^{-8}$ and $8.6 \times 10^{-9} \mathrm{~m}^{2} / \mathrm{s}$ for $\mathrm{T}_{1}, \mathrm{~T}_{2}, \mathrm{~T}_{3}$ and $\mathrm{T}_{4}$ respectively. Based on these results, $\mathrm{T}_{3}$ had the highest effective moisture diffusivity compared with other treatments. The minimum total energy consumption $(0.08 \mathrm{kWh})$, the minimum specific energy $\left(5.7 \mathrm{MJ} / \mathrm{kgH}_{2} \mathrm{O}\right)$ and maximum drying efficiency $(40 \%)$ were computed for drying dates samples $\left(\mathrm{T}_{3}\right)$. The maximum total energy consumption $(0.14 \mathrm{kWh})$, the minimum drying efficiency (32\%) and maximum specific energy (7.15 $\mathrm{MJ} / \mathrm{kgH}_{2} \mathrm{O}$ ) were computed for drying dates samples $\left(\mathrm{T}_{1}\right)$.

\section{REFERENCES}

Adedeji, A.A., T.K. Gachovska, M.O. Ngadidi, and G.S.V. Raghavan, (2008). Effect of pretreatments on drying characteristics of okra. Dry. Technol. 26, 1251-1256. 
Agrawal, Y. C., \& R. P. Singh, (1977). Thin layer drying studies on short grain rough rice. ASAE, Paper No: 3531.

Arumuganathan, T., M.R. Manikantan, R.D. Rai, , S. Anandakumar, and V.Khare, (2009).Mathematical modeling of drying kinetics of milky mushroom in a fluidized bed dryer. Int. Agrophysics 23, 1-7.

Chhninman, M. S. (1984). Evaluation of selected mathematical models for describing thin layer drying of in-shell pecans. Transactions of the ASAE, 27, 610-615.

Crank, J. (1975). The Mathematics of Diffusion, Clarendon Press, Oxford, U.K..

Demirhan, E. and B. Ozbek, (2011). Thin-layer drying characteristics and modeling of celery leaves undergoing microwave treatment. Chem Eng Com, 198, 957-975.

Diaz, G.R., J.Martı'nez-Monzo, P.Fito, and A.Chiralt. (2003).Modelling of dehydration-rehydration of orange slices incombined microwave/air drying. Innovative Food Science \&Emerging Technologies, 4(2): 203-209.

Falade, K.O. and O.J. Solademi, (2010).Modeling of air drying of fresh and blanched sweet potato slices. Int. J. Food Sci. Technol. 45, 278-288.

FAO (2011). Statistical database. http://faostat.fao.org/site/ 567/desktop default. Aspx ? Page ID=567\#ancor.

Hayes, G.D. (1987). Food Engineering Data Handbook. England: Longman Scientific and Technical.

Hassini, L., S. Azzouz, R. Peczalski, and A. Belghith, (2007). Estimation of potato moisture diffusivity from convective drying kinetics with correction for shrinkage. J. Food Eng. 79, 47-56.

Kaya, A., O. Aydin, and C.Demirtas, (2009). Experimental and theoretical analysis of drying carrots. Desalination 237,285-295.

Lee, J.H. and H.J. Kim, (2009). Vacuum drying kinetics of Asian white radish (Raphanus sativus L.) slices. LWT - Food Sci. Technol. 42, 180-188.

Liu, Q., \& F. W. Bakker-Arkema, (1997). Stochastic modeling of grain drying, Part 2: Model development. Journal of Agricultural Engineering Research, 66, 275-280. 
Maskan, M., (2000). Microwave/air and microwave finish drying of banana. Journal of Food Engineering, 44(2): 71-78.

Minaei, S., A. Motevali, E. Ahmadi, and M.H. Azizi, (2012). Mathematical models of drying pomegranate arils in vacuum and microwave dryers. J. Agr. Sci. Tech, 14, 311-325.

Mousa, N., and M. Farid. (2002). Microwave vacuum drying of banana slices. Drying Technology, 20(10): 2055-2066.

Madamba, P.S. (2003). Thin layer drying models for osmotically predried young coconut. Dry. Technol. 21,1759-1780.

O’Callaghan, J. R., D. J. Menzies, \& P. H. Bailey, (1971). Digital simulation of agricultural dryer performance. Journal of Agricultural Engineering Research, 16, 223-244.

Soysal, A. (2004). Microwave Drying Characteristics of Parsley. Biosystems Engineering, 89(2): 167-173.

Soysal, A., S. Oztekin, and O. Eren. (2006). Microwave drying of parsley: modelling, kinetics, and energy aspects. Biosystems Engineering, 93(4): 403-413.

Zogzas, N.P., Z.B. Maroulis, and D. Marinos-Kouris, (1996).Moisture diffusivity data compilation in food stuffs. Dry. Technol. 14, 22252253.

Zhang, Q., \& J. B. Litchfield, (1991). An optimization of intermittent corn drying in a laboratory scale thin layer dryer. Drying Technology, 9, 383-395.

Tippayawong, N., C. Tantakitti, and S. Thavornun., (2008). Energy efficiency improvements in longan drying practice. Energy, 33(7): 1137-1143.

Vadivambal, R., and D.S. Jayas., (2007). Changes in quality of microwave-treated agricultural products-a review. Biosystems Engineering, 98(1): 1-16.

Rayaguru, K. and W. Routray, (2011). Microwave drying kinetics and quality characteristics of aromatic Pandanus amaryllifolius leaves. International Food Research Journal,18(3),1035 -1042.

Wang, C. Y., \& Singh, R. P. (1978). A single layer drying equation for rough rice. ASAE Paper No: 3001. 
Westerman, P. W., G. M.White, \& I. J. Ross, (1973). Relative humidity effect on the high temperature drying of shelled corn. Transactions of the ASAE, 16, 1136-1139.

Yongsawatdigul, J., and S. Gunasekaran., (1996). Microwave vacuum drying of cranberries, Part II: Quality evaluation. Journal of Food Process Engineering, 20(12): 145-156.

\section{الملخص العربيى}

استهلاك الطاقة و النمذجة الرياضية لتجفيف البلح بالميكروويف البريف

$$
\text { "منى محمود عبد العزيز حسن }
$$

يهدف البحث إلى تجفيف نو عين من البلح ، و هما الحيانى و الز غلول بواسطة الميكروويف فى

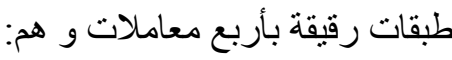

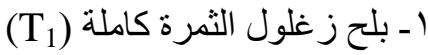

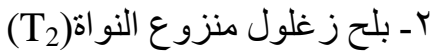

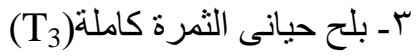
ـ ـ بلح حيانى رطب منزوع النو اة و القشرة (T4)

و حساب استهلاك الطاقة فى تجفيف كل نوع و مقارنة سلوك التجفيف مع ستة نماذج رياضية للتجفيف وكانت النتائج كالتالى:

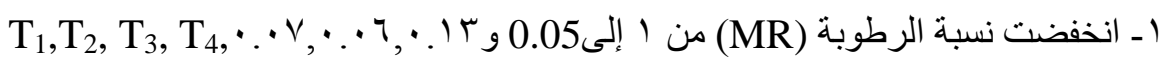

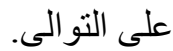
r ـ كانت اقل طاقة مستهلكة (5.7 MJ//kgH2O و اعلى طاقة مستهلكة (7.15 MJ/kgH $)$ (7.15)و اقل كفاءة(

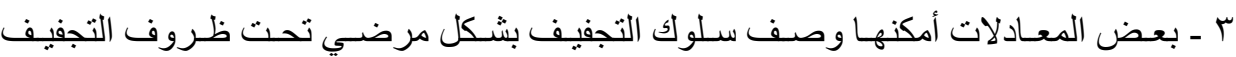

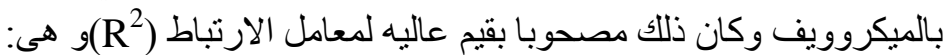

Page ,Modified Page (I) and Linear.

ـ ـ كان تأثير انتشار الرطوبة على المعاملات على التو الي. "أستاذ مساعد - قسم الهندسة الزراعية - كلية الزراعة - جامعة الزقازيق - مصر. 